\title{
DIASPORIC IDENTITY, HERITAGE, AND "HOMECOMING": HOW SARAWAKIAN-CHINESE TOURISTS FEEL ON TOUR IN BEIJING
}

\author{
CAROLINE TIE* AND TONY SEATONं \\ *Division of Tourism and Leisure, University of Bedfordshire, Bedfordshire, UK \\ $\dagger$ Department of Economics, University of Limerick, Limerick, Ireland
}

\begin{abstract}
The Chinese have become one of the most widely dispersed races across the globe. Yet they have often implicitly resisted this dispersion by a powerful, but often unspoken, mythic commitment to the image of China as an enduring homeland, rather than accepting any irreversible transfer of cultural allegiance and identity to the receiving country. Part of this myth of temporary exile, held and cherished by some diasporic groups, has been the dream of "going back," the return to one's roots. Increasingly, modern tourism apparently offers an easily accessed and temporary mechanism for going back to a Chinese "homeland" and seeking to discover and explore authentic Chinese identity. This article focuses on the possibilities of diasporic reconnection through tourism and specifically the role of heritage tourism encounters in an ethnic homeland from which some have been separated for long periods, and others have never seen. It explores theoretical and empirical issues attached to diasporic identity and "homecoming" tourism, using case study data collected from Chinese diasporic tourists from Sarawak on a package tour of China. In presenting the results, the analysis adopts a dual interpretative approach to heritage that evolved from the data analysis, in which it was decoded by the tour party members as both observations of the quotidian cultural activities and values of the Chinese people, and observations of the selective constructions of public culture provided and promoted by public agencies. The two perceived aspects of heritage generated contradictory responses within the tour party that were partly a reflection of perceptions and judgments about the intrinsic features of things observed (e.g., their authenticity and social acceptability). They were also due to differences in the backgrounds of members of the diasporic party in terms of language resources, span of generational residence in Sarawak as emigrants from China, and religion.
\end{abstract}

Key words: China; Heritage; Identity; Sarawakian-Chinese

\section{Introduction}

Before exploring the ways in which heritage encounters during "homeland" tours may affect members of Chinese diasporas in their evaluations of their identities, it is important to specify how the concept of heritage has been theorized and operationalized in this study. The article has adopted two interpretative approaches to heritage that seemed particularly apposite as a framework for analysis as 
the study progressed. These approaches conceptualized heritage as:

a) subjective/quotidian perceptions and enactments of a culture by its members and

b) heritage as the selective constructions of a culture provided and promoted by public agencies, particularly the state.

\section{Heritage as Subjective/Quotidian Perceptions of Culture}

Private-quotidian heritage comprises the subjective, self-perceptions of a community about its past and its relationship to its present, expressed and enacted in cultural performances by groups and individuals of daily and periodic rituals that encode norms (moral, aesthetic, occupational, etc.). These performances may comprise material practices, productive and reproductive activities, and embodied religious values and traditions. Together these constitute the continuities of a lived, and living, culture. This inclusive notion of heritage as a community's "whole way of life" and its historic understanding of its past has been viewed in heritage tourism discourse to comprise two main components"tangible" and "intangible" heritage (Ashworth \& Larkham, 1994; Boyd \& Timothy, 2002; Graham, Ashworth, \& Tunbridge, 2000; Jamieson, 1993; Nuryanti, 1996). Tangible heritage comprises the visible, built, and material dimensions of cultural heritage (its secular and religious buildings, memorials, artifacts, sculpture, art, etc.), whereas intangible heritage has been seen as the evanescent, human performative aspects of culture (music, dance, diet, popular narratives, customs, rituals, etc.). Both comprise selective and preferred visions of the past, although the scope for social construction and imagining is much greater in relation to intangible heritage where there is little or no physical evidence from which to witness directly, or from which to construct, the past.

For diasporic visitors to a former homeland, observations and encounters with the daily "lived" culture of its people, as here described, may be an important way in which they measure the similarity or dissimilarity of their own cultural heritage against that of the indigenous population, with whom they may expect beforehand, to a greater or lesser extent, to share common bonds of identity.

\section{Heritage as the Selective Constructions of a Culture Provided and Promoted by \\ Public Agencies}

The second interpretation of heritage pertains not to performances and self-perceptions by groups of their cultural heritage but to exhibited and mediated constructions of it, externally provided by public agencies. According to this interpretation, heritage constitutes a more restricted range of cultural objects, artifacts, and customs (architectural, artistic, historic, ceremonial, mythical), which are officially nominated, privileged, valorized, and, often, exhibited for "auratic" acceptance and display (e.g., in schools, galleries, museums, memorials, and public spaces) to both domestic populations and international visitors. These officially authorized constructions of national heritage by institutionalized agencies may comprise representations of both tangible and intangible heritage. They are virtually synonymous with what Horne (1986) has designated "public culture," defined as "the language used to enact the dominant myths of a society" (p. 59). Within this definition he characterized "myth" as "a belief held in common by a large group of people that gives events and actions a particular meaning" (p. 57) that could be encoded not just in words but in other symbolic practices including visual images, sounds, artifacts, and activities. Public culture and heritage as an officially approved version of culture both lay claim to being a reflection of the collective identity of a nation.

Ideally, there will be overlap and congruence between the two versions of heritage interpretation. Subjective evaluations of a community's heritage by indigenous populations may accord with official narratives and displays, which has led one writer to describe heritage sites as "instrumental vehicles for collective memory (e.g., memory ... symbolic) symbolic places or cultural expressive sites . . . that anchor shared emotional attachment" (Corcoran, 2002, p. 6).

But emotional attachment to all aspects of official culture is not guaranteed and may not be equally shared. The two operate differently in people's minds. Where subjective understandings and enactments of heritage by a cultural group are generally 
experienced as personal, spontaneous, and natural, constructions that are officially provided for anonymous, public consumption may be interrogated on the grounds of their accuracy and authenticity. In extreme instances they may be contested, denied, and seen as alien impositions running counter to the subjective verities of quotidian lived culture and the authenticity of an imagined ancestral past. Cultural fault lines and heritage anomalies are particularly likely to happen in multiracial and ethnic societies, where there are several populations of immigrant extraction as well as diasporic groups returning to them, both of whom may have, or come to have, quotidian cultures different from those celebrated and authorized in the narratives of official culture.

The two different versions of heritage contrasted here raise vital issues that invariably operate when diasporic groups undertake homeland trips to their countries of origin and are confronted by both the quotidian culture of the people there and the displays of public culture exhibited as national heritage, with both of which they might expect to identify through some happy shock of mutual, ancestral recognition.

It is for this reason that this study of the diasporic experiences of homeland returners is centrally structured around an analysis of the two kinds of heritage and the differing effects they produced in the minds of the Sarawakian-Chinese tourists, particularly the degree to which they renewed, consolidated, or created feelings of self-identification with Chinese culture and China as an extant homeland.

\section{Diasporas, Heritage, and the Contradictions of "Home"}

Diasporic groups are particularly problematic in relation to heritage because they are confronted by a dilemma, which is that their past is rooted in two places - an original but retreating one in a homeland from which they emigrated and a newer but perpetually increasing past in that to which they immigrated. The discourse of diasporic groups recently arrived, or based, in a new country often assumes an articulated commitment to homeland as the place they have departed from (Falzon, 2003; GlickSchiller, Basch, \& Blanc-Szaton, 1992; Safran, 1991). Authors have contended that this homeland is a place of significance because it provides a sense of association of identity for the exiles and is perceived by the diaspora to possess core cultural values that are uncontaminated by the "pollution" of other cultures or other elements of change (Basu, 2004; Brubaker, 2005; Soysal, 2000). Visits to heritage sites on return trips to their homeland thus have the potential to strengthen ethnic identity and provide personal meaning in the lives of the diaspora.

\section{Aims of the Research}

The general research objective of this article focuses on how diasporic Chinese individuals and groups respond to homeland trips, primarily through their engagement with heritage (both official public culture and quotidian culture). More specifically, the aims are

a. to identify variations and differences by different diasporic generations (i.e., younger and older members of the research groups),

b. to track differences in impacts of visiting different kinds of heritage site during the tour, and

c. to distinguish, where possible, the different effects of the quotidian perceptions of Chinese heritage (as lived culture) and aspects in official constructions of exhibited "public culture."

\section{The Case Study}

The study is based on empirical case study data collected from Chinese diasporic tourists from Sarawak on a package tour of China. For the Chinese who have settled in Sarawak, their identity construction has been subjected to varying perceptions and forces of political, cultural, and social hegemony of Malaysian society. In the study of Chinese diaspora, G. Wang (1999) argues that the diaspora community is not a homogeneous group of people who live in the margins and that emphasis should be placed on "the difference and diversity within the diaspora in order to open up the perspective of a diasporic pluralism, one that recognizes that there are 'many kinds of Chinese,' even 'many different Chinese diaspora"' (p. 17), variously settled in and oriented toward their new countries of residence. Consequently, this article looks at the ways in which the Chinese diaspora tourists respond to 
Chinese heritage and how their experiences at heritage sites affect the way in which they construct, deconstruct, and reconstruct their hybridized Chinese identity.

The Chinese and Diasporic Identity:

Theoretical and Historical Background

As an integral part of public culture, heritage takes the function of not just preserving aspects of the past but also representing the testimony of a community and/or a nation. It is a perpetual sign of the elements that exist (both tangible and intangible) and provides a symbolic foundation upon which a sense of belonging is constructed (Park, 2010). It demarcates between those who belong to a shared legacy and experience and those who do not. It informs and enhances the identity of those who claimed belonging and ownership and reflects a notion of inclusivity (Ashley, 2007).

However, this form of conceptualization is not without its problems because a demarcation between who belongs and who does not is often embedded in an implicit essentialism. It conceptualizes identity as having fixed cultural and historical traits that are predetermined by primordial forces. People recognize their sense of belonging by certain fixed qualities that are assumed to be universal and timeless. According to this view, people who belong to the same heritage would share a common and distinctive descent, culture, and history (Haslam, Rothschild, \& Ernst, 2000; Rothbart \& Taylor, 1992).

Proponents of this concept argue that even the Chinese diaspora who are born and live outside China would retain a racial essence connecting them to the Chinese in China. Balibar (1991) suggests that the idea of being part of the same ethnicity is to produce a sense of belonging based on naturalized and reiterating fictive notions of kinship and heredity. Therefore being Chinese is an essential, unalterable matter, rooted in biological forces and the genes. It is based on a fixed identity that ignores historical and social changes. It is an imminent and irreversible product of natural and biological phenomena, determined at birth (Connor, 1978; Isaacs, 1975). Hence, all Chinese diasporics would share the same sense of heritage as the Chinese in China.
Proponents of essentialism thus argue that there is only one form of Chinese identity. The meaning of being Chinese is to have similar historical, social, and cultural experiences across all geopolitical borders. The dragon, the Great Wall, and the Yellow River have long been regarded as the symbols of Chinese ancestry and the cradle of Chinese civilization. Speaking Mandarin and observing the "cultural" code of ethics are also part of the outward characteristics of being Chinese. China meaning the "center of the kingdom" (zhungguo), with its immense geographical size, its 5,000 years of cultural history and its distinctive language, supports a sense of cultural identity for Chinese people. As Tu (1991) explains:

... being Chinese is to belong to a biological line traceable to the Yellow Emperor, being born in the Divine Land, having the ability to speak the language and hence participate in the Chinese linguistic world; being Chinese also implies the practice of a code of ethics towards one's homeland the mother country. (p. i)

The typical characteristics of being Chinese are thus belonging to an old established race, speaking the Chinese language, and practicing rituals of Chinese culture. As long as the people with Chinese backgrounds can claim a male Chinese ancestor, an ancestor's birthplace in China, or practice some form of Chinese culture, they remain Chinese (Wu, 1994). Consequently, E. Chen (2002) argues that "being Chinese carries with it the expectations beyond the physical. It is a complete package: linguistic, historical, psychological as well as physical. In other words, it is both a natural and biological phenomenon to be Chinese" (p. 1).

This single homogeneous point of view has been criticized by Chambers (1994) as being established through the construction of an "imaginary community," a sense of belonging that is sustained by fantasy and imagination. In opposition to essentialism, antiessentialism recognizes that identity is continuously changing and is open to rerouting, rewriting, and questioning. The construction of identity is seen as a dynamic, hybrid process that is never completed where identity becomes a flexible zone, susceptible to multiple discourses (Mathews, 2000) and influences. Where discourses of heritage and its symbolic constituents are assumed to be static, 
their interpretation may be subject to multiple meanings by different Chinese diasporas. Antiessentialism posits that essentialism is inadequate for defining the changing nature of identity in response to global forces. The fluid movements of identity in a globalized world are seen as a journey that is often open and incomplete, in which there is no fixed identity (Chambers, 1994).

Since the late 1960s, as more Chinese have been born in peripheries and subjected to the influences of their respective diasporic countries, the meanings of being Chinese have had to be reexamined. This notion of a static "Chineseness" as originating from China is clearly problematic when applied generally to the community, given the diversity of ethnicity, religion, language, territory, and even nationality. For example, a person of Chinese descent living in America may negotiate practices of Chineseness in ways that are different from that of another who lives in Australia. Likewise, a Chinese person in Sarawak would not necessarily define their sense of Chineseness as would a Chinese person living in China.

Chinese identity, including the identity of the Sarawakian-Chinese, is therefore likely to vary due to cultural, social, political, and economic forces operating in the state of immigration. Thus, the meaning of Chineseness of these diasporic communities is subject to change in each locality, with ethnic Chinese communities developing distinct local consciousnesses in different parts of the world.

\section{The Chinese Community in Sarawak}

The subject of this research is the Chinese diasporic community residing in Kuching, located in the southwest of Sarawak. Sarawak is situated on the island of Borneo and is one of the 13 states of Malaysia. Since their independence, the Chinese have been the second largest minority population in the state. According to Skeldon (2003), the early migration of Chinese people during this period to Southeast Asia was "diasporic," with communities being established in different countries who maintained their links with their homeland. Several studies have indicated that Chinese migration in the early 19th century was due to various factors. Wars and famine within the country drove many abroad, and the dire need for cheap labor in foreign lands opened up opportunities for China's poor (Pan, 1999; G. Wang, 1991; L. L. Wang, 1994).

Historically, it was unusual for Chinese to leave home permanently. First-generation migrants saw themselves more as sojourners, as the traditions and expectations of kin in China meant they had responsibility toward those at home (Wickberg, 1994). Therefore, they were not expected to settle, but to return to their homeland eventually. However, through a combination of political changes in China and a pro-immigrant colonial policy in Sarawak, many migrants decided to stay. In 1957, Peninsular Malaya gained its independence from British rule, and in 1963 Sarawak became part of the Federation of Malaya, which was renamed Malaysia. Following independence, the Malaysian government granted citizenship to all Malaysianborn Chinese, including those born in Sarawak. The successive postindependence Chinese generations have since shed off this sojourning mentality and become more "localized and Malaysianized" in their identity (Tan, 2001, p. 215).

As the community has established itself in Sarawak, its relationship with the homeland has become more isolated. As they moved away from their homeland, their identity is becoming "undecidedly mixed with otherness" (Young, 1995, p. 50), and where they dwell among other people of different cultures, their own cultural practices continue to be negotiated, transformed, and rearticulated (Bhabha, 1994). Where sharing "a common ancestry, a history, and a shared symbol of peoplehood originated from China" (Cornell \& Hartman, 1998, p. 32) has brought the Chinese together, the changing political, economic, social, and cultural landscapes in the new land have shaped their identity to become increasingly heterogeneous.

In 1978, following Chairman Deng Xiao-Ping's reforms and "Open Door" policy, emigrants were permitted to return to China if they desired. Since then, many Sarawakian-Chinese have taken the opportunities to visit their ancestral homeland. The opening of the Chinese border and the subsequent renewal of contacts between Chinese diasporas and their relatives in China has led Nyíri (1997) to comment that the Chinese overseas are now reorienting their identity toward China. However, such claims have been disputed by several scholars (Tan, 2001; Tong \& Chan, 2001; Tu, 1991), who claim 
that during the three decades of disconnection from China, the identity of the Chinese diaspora and successive generations has changed. It is argued that as their identity becomes more heterogeneously hybridized, their (re)visits to homeland, like some diasporic groups, may lead to troubling, disconcerting, and ambiguous experiences as well as newfound ambivalences (Duval, 2003; Stephenson, 2002). Hence, this article assesses the theoretical and empirical issues related to heritage tourism in China as a means of providing diasporic groups with a passport to recovery and renewal of an identity, reconnecting them to an ethnic homeland they have been separated from for different periods and, in some instances, have never seen.

\section{Methods}

All the questions posed in these aims and explored in this study of diasporic reactions to homeland heritage were cognitive and affective ones, involving subjective meanings, personal images, and private attitudes relating to identity. In the light of these ego-involved issues, a qualitativeinterpretive methodology was adopted as one most likely to facilitate their exploration and also, as one commonly used in ethnographic studies of culture, travel and tourism (Bruner, 1995; Geertz, 1973). The specific instrument was unobtrusive, participant observation adapted from a previous study of a coach party engaged in a heritage tour of the battlefields of World War I (Seaton, 2002). In a methodological paper on this study, Seaton (2002) distinguished between two contrasting contexts of ethnographic observation in tourism research: open and closed field.

The closed-field context involves participant observation where the researcher and the subjects being studied "conjointly exist within a discrete, temporal, and spatial setting as co-actors in a drama" (Seaton, 2002, p. 311). Such bounded settings are found in several tourism contexts including all tours that involve shared transport by car, train, or air and living together for a finite period of time in common accommodation. The open-field context, by contrast, occurs when the researcher and the researched are not mutually confined within a spatial and temporal boundary, but are free to come and go as separate and independent actors during the period of the research. This open-field context is more common than closed-field observation and is almost always that used in anthropological field work. Seaton (2002) argues that the closed-field context is greatly superior to the open-field context for in-depth exploration of tourism involving group travel because it eliminates difficult decisions about how the researcher should gain access to, enter, and exit from the research population under study because everyone, researcher and researched, starts off equally as outsiders, when they begin as participants in a coach tour, and gradually became insiders through the progressive, internal dynamics of membership of the tour group (Seaton, 2002). It also allows close contact with and observation of the subjects, under natural conditions, during the daily tour schedules. It also makes possible reflective feedback from the subjects outside the actual tour schedules, at meals, and in free time back at the accommodation. It is these attributes that, according to Seaton, make closed-field tours a "mobile laboratory" for researchers using unobtrusive, participant observation to study tourists (Seaton, 2002).

The participant observation with a tour group of Sarawakian-Chinese to China took place over a period of 9 days in October 2005. The rationale for visiting China with a party of tourists was for the purpose of observing the tourism experiences of the Sarawakian-Chinese in the ancestral homeland. The purposes of observing their behavior were to explore how a (return) visit to the ancestral homeland might cause the participants to reassess their identities. Therefore, everyday conversations, casual discussions, and patterns of behavior of the study group were significant activities that were then recorded in a diary.

\section{The Tour Sample Group}

The tour group consisted of 13 individuals and a tour representative from Sarawak, Malaysia. Background information on each individual was gathered in informal conversation during "free time" in the evening and during meal breaks. The tour group included four males and nine females (including the researcher), of whom six were aged above 60 , three were below 30 years old, and the rest were aged between 30 and 60 . Prior to this visit, five 
participants had visited other sites in China, and only one had visited Beijing, Tianjin, and Chengde. Two members had been born in China but had since settled in Sarawak, five participants were secondgeneration diaspora, and six were from the third generations. Most of the group members could speak and read Mandarin. Our social conversation was mainly in Mandarin and other local dialects, punctuated with English words.

\section{Findings}

\section{Heritage as Exhibited Public Culture}

The tour comprised visits to 12 sites and events that constituted exhibited culture. The tour spent the first day visiting the Forbidden City and the Jiao Zhuang $\mathrm{Hu}$ Underground Tunnel. On the second day, the group was taken to the Great Wall, the Wax Museum, and Temple of Heaven. The following day, there were visits to the Summer Palace, Heavenly Garden, and Ming's Tomb and an excursion through Hutong on rickshaws. On the fourth day, the trips were to the Corner Tower of Beijing City, and the tour group also spent 2 days in Chengde where visits comprised the Summer Resort and the Potala Temple. Most of these sites displayed the extravagance and grandeur imputed to previous dynasties and were narrated by the guide as ones that "spoke" of national pride and Chinese identity, which found ready responses among tour group members:

I thought it was quite impressive with the Ming's Tomb. The emperor could design the tomb in such a way that the last person would be locked in with him so that the person wouldn't be able to steal the gold and get away with the emperor's wealth. He was a very clever man. (woman, first generation)

Ya, they know how to keep themselves warm during the winter and how to keep themselves cool during the hot summer. They built the whole palaces without the use of a single nail. They were able to carry the heavy stones up the steep mountain to build the wall - they say you can see the wall even in outer space! How amazing is that. The Chinese people should be proud for their achievements. (woman, second generation)

Wow! Look at the architecture of the palace [the Imperial Palace], the Chinese people are geniuses. You do not see this in other places in the world.
The architectural design is fantastic. When you see the design, you really must admire the Chinese people. I think "we" are pretty good in astounding the world, don't you think? Malaysia should be proud of having Chinese people. Chinese people are the same all over the world. Wherever we go, we are innovative and creative. It's in our DNA. (man, third generation)

On the group to the Forbidden City, gaining understanding and being educated in its history were prominent in the responses of the members visiting China, particularly among the first and second generations. Some of the Sarawakian-Chinese were evidently more knowledgeable of this heritage site than others in the tour group. However, it was the broad strokes of Chinese history as one that extended back 5,000 years that was played back, often over meal times, as a source of identification and pride by all the tour group members, rather than specific details of that history. For instance:

I don't think my grandchildren know their Chinese history at all. They don't learn that in school. I feel proud to be Chinese because of this history but I don't think my grandchildren understand that sense of pride of being Chinese. They think they are Chinese because they are not Malays. I think they should come to China. (woman, first generation)

The history of the City [Forbidden City] is very interesting indeed. Considering the Chinese people built all these and these buildings are still standing today. We are descendents of a great civilization. It is important to recognize this particularly if we don't have that sort of long history in Malaysia. We also don't have that kind of history and presence in Malaysia. We don't have that heritagewell except for that Buddhist temple, which is the oldest in Kuching but compare [ $\mathrm{sic}]$ to the one here, it's nothing. (woman, second generation)

This trip is very educational. I learnt about Chinese history when I was in Chinese schools. But I never knew how much I didn't know until now. We have visited several places today and the tour guide has been telling us of "our" 5,000-year history. I am amazed and very overwhelmed. I didn't know "we" have so much history. (woman, third generation)

These reactions reflect a pretty well exact conjunction of the implicit, official agendas of "Public Culture" intentions and the responses of their audiences 
across the three generations. There were no critical or adverse comments, and the evident willingness by the party to make the appropriate reactions of awe and approval reflected a complete acceptance of official narratives.

\section{Diminution of the Diasporic Host Country}

Assimilation of the longevity of Chinese traditions also produced a "shock of recognition" that acted as a springboard for discussion of identity, the long cultural legacy they shared, and a heightened sense of their Chineseness. This process of emphasizing and glorifying the historical achievements in China had a counterveiling tendency to diminish the perceived significance of Chinese history in Sarawak. In comparison to a 5,000-year history, two centuries of Chinese history in Sarawak were deemed "less impressive" and "less significant" in informing Sarawakian-Chinese identity. The following response exemplifies these perceptions:

I am very proud of being Chinese. We should all be proud of being Chinese because we have a 5,000 year of history. Although the Chinese came to Malaysia in the 19th century, so it is really a short history. I like to think we have a 5,000 year of history. I don't know what history we have in Sarawak. When you think about your Chinese history, you always think about China. You seldom think about Malaysia. You think about the great dynasties of the past then you think about the Chairman Mao and Deng and all other politicians and how they propelled the nation forward. (man, first generation)

These extracts indicate the powerful impact produced by the narrative of China's 5,000-year history. The emphasis the guide gave to the 5,000-year trope was repeated like a mantra over the 9 days of the tour. Although the tour guide was extremely competent in her detailed explanations of Chinese history, one of the researchers was finding it very difficult to remember and to process all the information that she gained. However, upon the researcher's return to Sarawak, when asked what she remembered most about her 9-day tour to China, she found herself echoing the same phrase: "China has a 5,000-year history." This perhaps suggests the potency of the phrase as a tag line that seemed to "indoctrinate" the Sarawakian-Chinese into wanting to appropriate it as part of their group identity.
Having knowledge of where they came from and who they once were gave them a (re)new(ed) sense of identity. It (re)emphasized their existence, shifting from the "unknown" or "less" known to the (better) "known." A commonality of sentiment among the tour group members was that they held Chinese culture in China to be "authentic" vis-àvis the one in Sarawak which was "less authentic." However, it was possible to distinguish differences and variations among the three generations:

When I was a child, we used to take the bicycle like they do now. Something don't change. [have you been here before?] No. I was born in the village. We can't afford to travel like this. This place is our culture. It is our heritage. China is where all Chinese people come from. It is in our blood. Your heritage is here. I try to tell my grandchildren that one day they should come to China to experience "real" Chinese themselves. (man, first generation)

Ya, but you were born here so you would feel more Chinese than us. Did you notice the older people when we were at Hutong, some of the houses look like nothing has changed. Everything was very old-fashioned and even the people looked like what I imagined them to be. Some of the older people look like my father. They are very Chinese [sic]. More Chinese than we are! [what do you mean]. Well, you know. . . . Them being in China so their culture is pure and we are "less" so [sic] ... I suppose being influenced by other cultures like the Malays, so it is not that authentic anymore, a "diluted" culture [sic]. Being here, you know you are Chinese like "them" but you also know you are different. (man, second generation)

I don't know too much about the history of some of the places that we went to. I heard of them and seen the pictures but I don't know who was the emperor then and what he did, etc. I get so confused with what the tour guide was saying. I think she (the tour guide) just assumed we knew the Chinese history because we are Chinese. I think she would be disappointed to know that I am not as Chinese as she thinks. I may not know my history or the heritage in China (well it helps to knownow that I am here) [sic] but I am still Chinese. I can prove with my birth certificate but she won't understand it. (woman, third generation)

As these examples suggest, these tourists continued to view China as the reference point of all things Chinese and therefore China as the center in which they structured their existence and identity. China 
being the center of Chinese culture was perceived to possess all things pure, and these tourists saw themselves as dwelling in the periphery where their Chinese culture was considered to be relatively "less" authentic because it was tainted by other cultures. They judged and measured Chineseness based on proximity, the nearer one was to the center of the culture, the "purer" it was. However, as reflected in their identification of being Chinese, the first generation implied Chineseness as given at birth, a product of natural and biological phenomenon (Connor, 1978; Isaacs, 1975). For the second generation the concept of being Chinese was relationally positioned, recognizing they were Chinese because they were not Malays and the third generation's concept of identity was one that was ascribed to them. Despite these differences, there was a general sense of their own identity as hybridized and therefore increasingly "less" Chinese, which supports the academic literature.

\section{Authenticity and Myth}

Despite the impact of public heritage there was an embryonic impetus to interrogate its authenticity. In the tour of the Wax Museum, for example:

I read some of the history before and when I was reading the history, some parts did seem like just story to me. I don't know whether they are just stories or not but when you are here, walking the palace gardens, you wonder if they are all real after all. (woman, second generation)

Listening to the tour guide made me realize that everything she said is really part of my heritage. I don't know whether some of the stories are actually true or whether they are just make-believe, you know like Chinese fairy-tales that sort of things [sic]. You know like some of these mythic creatures outside the doors were supposed to protect the emperors. Even if the stories are not true, so what? [sic] These stories are part of our rich heritage. I can't think of other countries who would have that kind of history and stories all mixed together. (woman, third generation)

A coherent theme arising from these narratives is that of a sense of belonging to a heritage despite the fact that some of the stories cannot be truthfully verified. The consensus among all the members of the group seemed to suggest that these stories were entertaining and everyone nodded in agreement that "these stories are our heritage." Having a history and/or myth, possessing a heritage separated "us" as Chinese from "them" who were nonChinese. These tourists were not too concerned with the authenticity of the history because these "stories" were perceived to be interwoven into their heritage and therefore were significant to them. Interestingly, this typological tendency to magnify the importance of symbolic, mythic meaning at the expense of literal, verifiable truth represents an approach to allegory that has existed in traditions of Christian biblical exegesis, as well among anthropologists (e.g., Levi-Strauss).

\section{Religious Perceptions}

Just as Chinese myths and practices were significant as cultural components producing identification among Sarawakian-Chinese visiting China, experiencing religious practices was also important. Members of the party recognized that religion in China was mainly influenced by Buddhism, and those who were Buddhists found they could relate to it and subsequently participated in religious rituals and practices. In addition to Buddhism, the rituals of ancestor worship were also particularly prominent in the lives of the Chinese community, involving the burning of incense and giving offerings to their ancestors. Again, Buddhists in the group viewed these practices favorably as rituals that were signs of filial piety toward their ancestors:

I've been on other tours before and I have to say these tours are quite similar in many ways. They take you to various palaces and also Chinese temples. The Buddhist temples are part of [our] heritage so all these tours would include visiting temples. (woman, first generation)

I came along to this trip with my girlfriend because I was curious about China. The tour guide is telling us some interesting history of China but I find it very difficult to understand everything because I can't understand Mandarin. My girlfriend is doing her best to translate everything into English but still I feel I don't relate to this aspect of Chinese culture like the rest of the group. The only thing I do find meaningful is our visit to the temples. At least in the temple, my girlfriend doesn't need to explain everything because I know what to do in the temple. That is the only aspect that I feel 
slightly more in touch with the Chinese culture. (man, third generation)

During visits to the temples, those who were Buddhists would engage in prayer and worship, while non-Buddhists remained outside. A conflict between religious faith and identity emerged during the tour to many temples, including the visits to the Temple of Heaven and the Potala Temple, with the Buddhists expressing a closer alliance to Chinese culture than the Christian converts:

I don't know how many temples I've seen in the last few days. It's good in a way because the Buddhists can pray there. But for me, I'm a bit bored. I have been on several tours to China and they always take you to these temples. I would prefer not to go at all but going to these temples are part of the tour because it was considered as part of the Chinese culture. I think Buddhist temples are part of the Chinese heritage. Are you a Christian? I'm Catholic. (man, first generation)

While I was outside the temple, there was another group of tourists there. I met the tour guide and the tour members were from Sabah [another state in Malaysia]. All of the tour members were Christians but they still have to visit Chinese temples nevertheless. I don't think the Chinese tour guide understands the difference between our Chinese in Sarawak and the Chinese here. I think if you are Chinese, they just assume you would want to visit temples because you would want to burn incense for your ancestors. (woman, second generation)

The Christians' sense of detachment suggests that the Chinese traditions of visiting temples were a symbolic representation of a religious identity, some of them no longer shared. As the Christian Sarawakian-Chinese did not see any congruence between their faith and the Chinese heritage, they expressed little interest in visiting religious sites in China. Thus, religion acted as a divisive force in group identity, even though all were from Sarawak and of Chinese descent. This indicates the continuing importance of religious belief as a core anthropological attribute that is less amenable to negotiation of hybridization than others.

\section{Invented Traditions and Fake Authenticity}

Visiting Chinese were also taken to the Corner Tower of Beijing City. This housed a sculpture in the form of a mythical beast with the physical form of a dragon's head, a horse's body, a lion's claws, and the horns of a unicorn. The tour guide explained that in ancient China, this mystical creature was solely for imperial use. However, in modern China, the beast, which is called "Pi Xu," is considered as a feng shui guardian, a dispeller of evil spirits and bringer of good luck. In the last few years, the Pi $\mathrm{Xu}$ has been made accessible to all who can afford to purchase miniature replicas of these creatures as souvenirs. The tour guide demonstrated ways in which this mythical beast could be used to invoke good luck in different situations, including bringing prosperity to the office and good luck to the home. After the demonstration, the group was encouraged to touch the "beast" in order to enjoy good health and prosperity. Some of the Sarawakian-Chinese participated in the rituals, while others held back without saying why.

When the party returned to the coach, it was learnt that the ritual touching of the beast confused and disturbed some of the tour members. The Buddhists were uncertain whether the ritual was part of their religious practice, while the non-Buddhists were skeptical of the whole ritual, arguing that it was just another "superstitious gimmick" constructed by the Chinese Tourism Board! Since none of the tour group members were familiar with either the beast or the ritual, they were not sure whether it was part of their Chinese religious heritage. The Sarawakian-Chinese were not sure how they would define such experience or identify with this practice as part of their heritage. The researcher later learned that this feng shui practice was only made popular by the Chinese in China in the late 1990s. Even those who had participated in a similar tour to Beijing a few years before were not familiar with the practice. It suggests that new Chinese traditions are invented and constructed to embellish and animate perceptions of Chinese heritage among tourists and also to generate revenue.

\section{Heritage-A Unifying Symbol of Identification for All}

At a more recent heritage site, the tour group visited the Jiao Zhuang Hu underground tunnel, which in the 1940s was built to protect the local people from the Japanese invaders. While the Chinese tour guide waited for all the tour members to arrive at 
the entrance, she explained that the tunnel was the ingenious invention of Chairman Mao and his army against the enemy. The locals survived many days in the tunnel. While those who had arrived earlier had listened to the explanation, those who had arrived late missed what was initially said by the tour guide. Repeating the words of the Chinese tour guide, the Malaysian tour representative said: "The tunnel was built by the late Chairman Mao to protect [us] from being invaded by the Japanese. The tunnel saved [us] from the enemy."

The site became something of a heritage icon both for the Chinese in China and for the Chinese from Sarawak. The site instantaneously signified their solidarity against the Japanese enemy in which the enemy of China also became their enemy, and Chairman Mao became the protector of all Chinese people. The site was constructed in official narrative and accepted by the visitors as an exclusive place in which "we" the Chinese were invaded by the "others." Other sites, including all the palaces, evoked similar responses and were hailed by the Sarawakian-Chinese as monuments symbolizing their own identity. "Their" achievements, history, and heritage became "our" achievements, history, and heritage. Thus, the boundary between "us" and "them" became blurred at iconic sites of particular historical significance. The significance of visiting museums and absorbing narratives of China's importance as a great empire and innovative civilization was to magically heal the hybridized identities of Sarawak-Chinese, making them one under the cultural umbrella of grand myth and heritage.

\section{Industrial Tourism as Intangible Heritage: Commodification and Managed Trip Authenticity}

Besides the 12 sites, the tour group also visited various factories producing silk, crystals, jades, and pearls. These products were promoted as products used by emperors and empresses during their reigns. A tale was told of how a silk duvet cover was made especially for emperors to keep them warm in the winter and cool during the summer. This was woven into the tour guide's narration as the tour members visited the palaces and later rereiterated during visits to the silk factory. The same pattern of product placement within the narrations was repeated throughout visits to the crystal, jade, and pearl factories. After the third visits to these factories, one of the tour group members voiced his discontent:

First, it was the silk, then the crystal, and now the pearl. They are trying hard to promote and sell their products - telling us all these stories of how the empresses had used this powder made from pearls to keep her skin smooth and young. I don't even know which is true. Did they make up this story to make the product look more attractive? I'm not convinced that all of the stories are really true. (man, third generation)

To which his friend replied:

If products can be sold, history can be sold too. How do you expect them to sell their products if they don't tell you the history. It makes it all seem real $[\mathrm{sic}]$. Maybe they just want to prove to us that the history is real by showing us what they used to have and use, that is, the pearl and the silk. (woman, third generation)

Both of these comments illustrated the complexity of knowing whether history in this case was constructed to authenticate the products, or whether the products were manufactured to authenticate the history concerned. Both tangible products and intangible history were commodities sold to tourists in China.

\section{Heritage as Observed Quotidian Culture}

During the tour, research observations were made of the tour members' perceptions and evaluative impressions of the quotidian culture and heritage of the Chinese, manifested in the practices and environments of their modern daily life, as well as that constructed at public sites in official discourses. Several expressed pride in being Chinese because China had now achieved an advanced stage of development. Visual observations on the tour coach were important to this perception, for example, the high-rise buildings and the number of expensive cars on the road were seen as evidence of a prospering modernity and progress to an "advanced stage of development" that were interpreted as signifying a maturing modernity among the Chinese that they incorporated within their own ethnic identity. China's economic development was a symbol of how all the Chinese had progressed, including the Sarawakian-Chinese. 
As the tour group described their positive experiences of visiting China, they included themselves as being part of the progressive race, often using the terms "we" and "us." The following responses illustrate this identification with the Chinese in China:

China is developing fast. "We" are becoming one of the economic powers in the region. Even America is afraid of "us." (Us?). I mean us-the Chinese people. The dragon is awake. We will show the world what we are made of. We don't bury our heads in the sand anymore. Look at us, we have moved to all parts of the world. Chinese can be found in every country. No matter how hard life is, we can make it. (man, first generation)

I have been to Beijing twice. I noticed there were less number of bicycles on the road the second time. Instead I saw many Mercedes Benz cars on the road. There were more high-rise buildings than before. This is truly a sign of development and progression. I am very proud to be Chinese because what you see in China, you know "we" are progressing fast. The West will have to compete with "us" now. Even if you were to compare the civilization 5,000 years ago, you would be fascinated by the way they constructed the palaces. How they learnt to construct such massive building without the use of a single nail and how they learned to transport the building material from one place to another were [sic] just amazing. This is really the genius of a Chinese mind. Where would the world be without us, the Chinese people? (woman, second generation)

This somewhat "triumphalist" and euphoric transformation from being hybridized, tourist observers of "them," to being players sharing as "us" in the drama of China's advance was encouraged in the narratives through which the guide commented and answered questions. This field entry exemplifies this:

Members of the tour group were very impressed with the economic development of China. Members of the tour group were fascinated by the motorways, overpasses, and the number of Mercedes Benz cars on the road. They were also impressed by the number of city towers in the urban areas. It was a while before a member of the tour group noticed that there were not as many bicycles on the road as he thought. The tour guide happily informed the party that China is a modern country and most people could afford a better means of transport. I guessed I would not be seeing streams of Chinese cyclists heading towards the sunset. (Field note entry: October 10, 2005)

For the Sarawakian-Chinese, to belong to a civilized and progressive group was to distance themselves from being identified as "uncivilized" and "backward," particularly for the first and second generation, who particularly articulated their identification with modern China as a progressive nation.

\section{Quotidian Culture: Responses of Hybridized Identity}

As the tour progressed, the separation between the Chinese in China and the Sarawakian-Chinese became more differentiated. The Sarawakian-Chinese distinguished themselves through the observation of culturally unacceptable social practices and breaches of etiquette. Spitting and begging were common in China and were perceived negatively by the group, reflective of a Chinese identity that belonged to China but not to Sarawak. When discussing this behavior many of the group members began to separate themselves from the Chinese in China. By doing so, they were not disqualifying themselves from being Chinese, but rather identifying themselves to be a different type of Chinese, a "refined" type of Chinese. As one of them commented:

Did you see "them" spitting outside the Wall? They spit everywhere. "We" are not like that. We don't see many people spit on the road or on the streets at home. Then there were the beggars. We were told to be careful because these beggars were aggressive. Chinese beggars are different from us. Chinese beggars were aggressive in the way they approach you for money. We are not aggressive like that. [Who do you mean by "we"?] I mean "us" the Sarawakian-Chinese. [What are we like?]. I think we are refined in our Chinese characteristics. (woman, second generation)

This comment suggest that the "what is" and "what is not" Chinese, is constructed by reference to the cultural norms of Sarawak. This permits an element of "pick" and "choose" of which parts of the cultural practices in China to be associated with. It also suggests that the meaning of being Chinese is not based on fixed entity but is socially constructed 
and the meaning fluid. In this instance, the close encounters with the "others" only served to affirm their Sarawakian-Chinese identity.

\section{The Tourists as "Others"}

On the other hand, traveling to China also reinforced their sense of hybridity as they were frequently treated as "tourists" or "outsiders." The experience of being treated as a tourist was endemic within the group visiting to China. The effect upon the psyche of the Sarawakian-Chinese was to destabilize their sense of belonging to China. As Sarawakian-Chinese, they are simultaneously cast as outsiders, thereby exposing them to new experiences of "otherness" in relation to their homeland:

I left here when I was a very young. My home is in Kuching. I brought up my children in Kuching and my grandchildren are in Kuching. I wouldn't want to live here even though my relatives are still here in the village. I left the country and I wouldn't think the government would want me back. But I wouldn't think of coming back here. (man, first generation)

What's wrong for being a tourist? I quite like it. It means you are only here for a few days and you can go home. I have no intention to live here. My parents and friends are back home. I don't think the Chinese government would be too accepting of us here either. (man, second generation)

They know we are tourists. Did you not notice, every time we come out from any attraction sites, there are people waiting for us, begging us for money . . . or they would be selling us various things. (woman, third generation)

The tour members referred to their "home" as a place where their family lived; they perceived themselves to be a tourist when they were in China. All the tour members claimed their home to be in Kuching and not China. Defining criteria of home were that it was a place of immediate family and familiarity; thus, Sarawak was home, whereas China was held to be a temporary place for visits. The attachment to Sarawak as home was underlined by their lack of desire to return to their homeland. They were also aware that it was not possible to settle in China because they would not be accepted by the Chinese government. Subsequently, it may be that for some of them, any desire to return to China permanently is not recognized or suppressed as a consequence of political realism. The expressed sentiment toward China was motivated more by a sense of being part of a "great civilization" and a sense of nationalism toward the Chinese culture, rather than a sense of patriotism toward the Chinese as a political grouping that is, an imaginary identification with history, not contemporary Chinese culture. None of the tour members sustained any longing for return to their ancestral homeland. The visits to China had challenged perceptions of their identity, and their experiences were instrumental in destabilizing their sense of belonging in China.

\section{Discussion}

It was evident for all three generations that their visit to China provoked considerable reflection on their past and present identities. The 5,000-year history of China was particularly embraced as a preferred "creation myth" of their own origins and "roots," but it had the counterveiling effect of making them diminish the heritage of their current homeland, Sarawak, as a subaltern nation with a puny history. Parker (1995) also found that association with the long history of China provoked a strong sense of ethnic identity for the Chinese diaspora. The public heritage exhibited at major national sites and the highly focused verbal discourses in which they were framed were successful in valorizing the length and importance of China's ancestral cultural legacy.

This perception that China was the cradle of all things Chinese reflected an essentialist ideology still resonant in the mindset of the diasporic Chinese, even though that identity was continually undergoing transformation (Tan, 2001). This concept of an "authentic" Chinese identity existing in China was and is founded upon identification with an "imaginary community" that is in effect, timeless, because of diasporic ignorance of the changes influencing modern culture of China. It was during the return visits to the homeland that this ignorance was dispelled as diasporic tourists were able to reconstruct and update their static images of the home culture. In the case of the Sarawakian-Chinese, this reconstruction still tended to reinforce a sense of the cultural authenticity of China. 
The results support notions of diasporic hybridity widely theorized in academic literature (Featherstone, 1996; Friedman, 1999; Lowe, 1991; Nurse, 1999). There was a general consensus among the three generations that, as the result of acquiring a "localized" Chinese consciousness in Sarawak, their sense of Chineseness had been diluted. Again this conforms to data on the emergence of hybrid identities through physical separation from China reported in other Chinese diasporic communities (Z. Chen, 2004; Suryadinata, 1987; Tan, 2001; Tong \& Chan, 2001; Tu, 1991; G. Wang, 1991). This sense of being "less" Chinese was reinforced in some encounters with the quotidian culture, where differences in behavior between the Sarawakian-Chinese and local people were not just observed but negatively evaluated in ways that articulated a social distance between indigenous Chinese norms of and SarawakianChinese etiquette. Studies of other diasporas have produced similar findings (see Conway \& Potter, 2009; Kibria, 2003; Louie, 2004; Maruyama \& Stronza, 2006). These perceptions of difference and social distance were particularly marked among third-generation visitors from Sarawak. For them there was some dissonance in their reservations about what they saw as indigenous Chinese behavior, given the fact that at home in Malaysia their own identity was officially and explicitly ascribed and fixed as Chinese in sociodemographic terms by the state that mandates every individual of Chinese descent to carry a birth certificate that specifies their ethnicity. Nevertheless, although visits to the homeland had served to heighten a sense of hybridity and challenge notions of "belonging" to China, the visitors still felt ethnically Chinese.

Religion played a significant role in the relative degree of connection the Sarawakian-Chinese felt to their ancestral homeland. The SarawakianChinese who practiced Buddhism responded more positively to temple visits and the rituals and practices displayed there. For Christians, the same practices, as well as incenses burning in temples, were seen as alien. This sense of unfamiliarity with, and alienation from practices in the temples, supports McDaniel and Burnett's (1990) observation that religion is a fundamental element of culture and that loss of religion, or conversion to another religion, may be an obstacle to engagement with religious aspects of public culture.
Although China is a significant reference point for appraising Sarawakian-Chinese culture, degrees of association with the Chinese culture varied within the community. As in the case of their encounter with the "mythical beast" at the Corner Tower of Beijing City, the group members were uncertain with this feng shui practice. It was not a practice that they were familiar with and not a practice they had in Sarawak. Their sense of "uncertainty" suggested that some of the Sarawakian-Chinese perceive their ethnic Chinese culture as similar to the Chinese in China. They identified their culture as similar to the one in China when they referred to the Chinese heritage and history as their own. Therefore, when they encountered a "new" tradition such as the ritual with the "pixu," the group was quick to perceive this as a "superstitious gimmick," one that was invented. Significantly though, since then, this "good luck charm" has been seen in many Sarawakian-Chinese homes and offices. This invented tradition has become part of the Chinese heritage.

The effects of the homeland tour reflected in the Sarawakian-Chinese tourists' responses to both the exhibited aspects of public culture, and to their less managed and subjective impressions of quotidian culture, were divided and contradictory. The effects of the tour were at different points, to both strengthen and weaken identifications with China as "motherland," but also to strengthen and weaken commitment and loyalties to Sarawak. These contradictory effects were partly due to differences in the tourists responses to exhibited public heritage (mainly positive), but more mixed reactions to the quotidian life in China; that is, modern development was held in veneration, therefore "together we are a progressive race" but the behavior of spitting and begging were held in disgust, therefore "we are not the same." The mixed reactions were also due to some skepticism and negative questioning of commodification, invented traditions, and authenticity at some exhibited public heritage.

It is important to note that all of the data collected were recorded during the trip. It is thus not possible to comment on the enduring impact of the perceptions recorded, which could only be assessed through a follow-up study. Although other studies have examined the impact of homeland tourism on specific diasporic travelers (Ali \& Holden, 2006; Ang, 1998; Baldassar, 2001; Basu, 2004; Christou, 
2003; Duval, 2003; Louie, 2004; Nguyen \& King, 1998), none has addressed the long-term effects of heritage encounters on perceptions of identity by diasporic tourists.

\section{Conclusions}

The tour began as an apparently simple and single journey of reconnection - a homeland return to China for a diasporic party whose members varied in their length of time in Sarawak, language facility, and religion. It began as one of broad, positive anticipations, rather than comprising any detailed blueprint of what "going back" might mean, particularly for those who had never previously visited China. Nor had it included prior consideration of the problematic spatial and temporal dimensions of the "where" to which the journey would lead, and the potential ambiguities and contradictions involved in responding to what was "there" (e.g., the lived culture of modernday Chinese, or the official culture constructed for public consumption).

This case study has attempted to narrate some of the complexities and contradictions of response by the diasporic party to the tour and the ways in which their experiences had an impact on their evaluation of their past and current identities. It has also sought to suggest reasons for the responses and relate them to previous academic findings in related studies. The results suggest variations and differences by diasporic generational differences. It is evident that the Sarawakian-Chinese are a heterogeneous group of people leading to emerging ethnicities and identities. Therefore, identity is better understood as being multiple, rather than singular in character, and continuously subject to reassessment and renegotiation rather than being fixed. However, some of the Sarawakian-Chinese, particularly the first generation, still feel connected with other Chinese diasporas across geopolitical boundaries and spatial distances, through both imagined and tangible common bonds. The crucial element in the discourse of the antiessentialist view of identity is that it allows identity to be defined outside fixed parameters of what it means to be Chinese. By visiting China, the Sarawakian-Chinese tourists were forced to reflect upon their own traditions and values as they confronted the experiences of "otherness." Ultimately, the evaluation and defining of their own identity can only be accomplished by reference to the "Other." Consequently, traveling to the ancestral homeland is a significant event, forcing the diasporic traveler to evaluate and redefine their sense of Chineseness and identity.

By visiting China and engaging with both the public culture and the quotidian culture, visitors imagined themselves as belonging to a great ancestral and now modernizing civilization. Whereas at times recognizing the fragmented and hybrid nature of their own identities during the tour, visiting public heritage sites and observing technological evidence of China's development on tour made available to them the possibility of identification with, and through, a greater essentialized version of being Chinese that could be incorporated as an enduring, if not exclusive element, of reevaluated identity. Official, public culture therefore served to forge and strengthen bonds of ethnic solidarity, convincing the visitors that that they were part of a heritage of 5,000 years. By contrast, however, some of their experiences with the quotidian culture of the local Chinese pushed them into a sphere of otherness where they felt they did not belong and wished to separate themselves from. The tour therefore both engendered a sense of shared but contradictory selfperceptions of being "Chinese" sometimes, being Sarawakian-Chinese as "others."

\section{References}

Ali, N., \& Holden, A. (2006). Postcolonial Pakistani mobilities: The embodiment of the "myth of return" in tourism. Mobilities, 1(2), 217-242.

Ang, I. (1998). Can one say no to Chineseness? Pushing the limits of the diasporic paradigm. Boundary, 2, 25(3), 223-242.

Ashley, S. (2007). The changing face of heritage at Canada's national historic sites. International Journal of Heritage Studies, 13(6), 478-488.

Ashworth, G., \& Larkham, P. (1994). Building a new heritage: Tourism, culture, and identity in the new Europe. London: Routledge.

Baldassar, L. (2001). Visits home: Migration experiences between Italy and Australia. Carlton South, Victoria: Melbourne University Press.

Balibar, E. (1991). Is there a "new-racism"? In I. M. Wallerstein (Ed.), Race, nation, class: Ambiguous identities (p. 232). London: Verso.

Basu, P. (2004). My own island home: The Orkney homecoming. Journal of Material Culture, 9(1), 27-42.

Bhabha, H. K. (1994). The location of culture. London: Routledge. 
Boyd, S. W., \& Timothy, D. J. (2002). Heritage tourism: Themes in tourism. Harlow, UK: Prentice Hall.

Brubaker, R. (2005). The "diaspora" diaspora. Ethnic and Racial Studies, 28(1), 1-19.

Bruner, E. M. (1995). The ethnographer/tourist in Indonesia. In M. Lanfant, J. B. Allcock, \& E. M. Bruner (Eds.), International tourism: Identity and change (pp. 224241). London: Sage.

Chambers, I. (1994). Migrancy, culture, identity. London: Routledge.

Chen, E. (2002, June 24). No place like home. South China Morning Post, p. 1.

Chen, Z. (2004). Building the Chinese diaspora across Canada: Chinese diasporic discourse and the case of Peterborough, Ontario. Diaspora: A Journal of Transnational Studies, 13(2), 185-210.

Christou, A. (2003). Narratives of place, culture and identity: Second-generation Greek-Americans return home. Unpublished Ph.D. thesis, University of Sussex, East Sussex, UK.

Connor, W. (1978). A nation is a nation, is a state, is an ethnic group is a. . . Ethnic and Racial Studies, 1(4), 377.

Conway, D., \& Potter, R. (2009). Return migration of the next generations: 21st century transnational mobility. Farnham: Ashgate.

Corcoran, F. (2002). The political instrumentality of cultural memory: A case-study of Ireland. Javnost-Public, 9(3), 49-63.

Cornell, S., \& Hartman, D. (1998). Ethnicity and race: Making identities in a changing world. Thousand Oaks, CA: Pine Forge.

Duval, T. (2003). When hosts become guests: Return visits and diasporic identities in a commonwealth eastern Caribbean community. Current Issues in Tourism, 6(4), 267-308.

Falzon, M. (2003). "Bombay, our cultural heart": Rethinking the relation between homeland and diaspora. Ethnic and Racial Studies, 26(4), 662-683.

Featherstone, M. (1996). Travel, migration and images of social life. In E. B. Gungwu (Ed.), Global history and migrations (pp. 239-277). Oxford: Perseus Books Group.

Friedman, J. (1999). The hybridization of roots and the abhorrence of the bush. In M. Featherstone \& S. Lash (Eds.), Spaces of culture: City, nation, world (pp. 230255). London: Sage.

Geertz, C. (1973). The interpretation of cultures: Selected essays. London: Hutchinson.

Glick-Schiller, N., Basch, L., \& Blanc-Szaton, C. (1992). Towards a transnational perspective on migration: Race, class, ethnicity and nationalism. Annals of the New York Academy of Sciences, 645, vii-xv.

Graham, B. J., Ashworth, G. J., \& Tunbridge, J. E. (2000). A geography of heritage: Power, culture, and economy. London: Arnold.

Haslam, N., Rothschild, L., \& Ernst, D. (2000). Essentialist beliefs about social categories. British Journal of Social Psychology, 39(1), 113-127.
Horne, D. (1986). The public culture: The triumph of industrialism. London: Pluto.

Isaacs, H. R. (1975). Basic group identity: the idols of the tribe. In N. Glazer, D. P. Moynihan, \& C. S. Schelling (Eds.), Ethnicity: Theory and experience (pp. 29-52). Cambridge, MA: Harvard University Press.

Jamieson, W. (1993). The challenge of cultural tourism. ICOMOS Bulletin, 3(3), 1-6.

Kibria, N. (2003). Becoming Asian American: Secondgeneration Chinese and Korean American identities. Baltimore: Johns Hopkins University Press.

Louie, A. (2004). Chineseness across borders: Renegotiating Chinese identities in China and the United States. Durham, NC: Duke University Press.

Lowe, L. (1991). Heterogeneity, hybridity, multiplicity: Marking Asian American differences. Diaspora: A Journal of Transnational Studies, 1(1), 24-44.

Mathews, G. (2000). Global culture/individual identity: Searching for home in the cultural supermarket. London: Routledge.

Maruyama, N., \& Stronza, A. (2006). Is this my home? Roots searching trip among Chinese Americans. Beijing: Centre for Research and Tourism Research.

McDaniel, S. W., \& Burnett, J. J. (1990). Consumer religiosity and retail store evaluative criteria. Journal of the Academy of Marketing Science, 18(2), 101-112.

Nguyen, T. H., \& King, B. (1998). Migrant homecomings: Viet Kieu attitude towards travelling back to Vietnam. Pacific Tourism Review, 1, 349-361.

Nurse, K. (1999). Globalization and Trinidad Carnival: Diaspora, hybridity and identity in global culture. Cultural Studies, 13(4), 661-690.

Nuryanti, W. (1996). Heritage and postmodern tourism. Annals of Tourism Research, 23(3), 249-260.

Nyíri, P. (1997). Reorientation: Notes on the rise of the PRC and Chinese identities in Southeast Asia. Southeast Asian Journal of Social Science, 25(2), 161-182.

Pan, L. (Ed.). (1999). The encyclopedia of the Chinese overseas. Richmond: Curzon.

Park, H. Y. (2010). Heritage tourism. Annals of Tourism Research, 37(1), 116-135.

Parker, D. (1995). Through different eyes: The cultural identities of young Chinese people in Britain. Aldershot, UK: Avebury.

Rothbart, M., \& Taylor, M. (1992). Essentialist beliefs about social category labels and social reality. In G. R. Semin \& K. Fiedler (Eds.), Language, interaction and social cognition (pp. 262-284). London: Sage.

Safran, W. (1991). Diaspora in modern societies: Myths of homeland and return. Diaspora: A Journal of Transnational Studies, 1(1), 83-99.

Seaton, A. V. (2002). Observing conducted tours: The ethnographic context in tourist research. Journal of Vacation Marketing, 8(4), 309-319.

Skeldon, R. (2003). The Chinese diaspora or the migration of Chinese peoples? In L. J. C. Ma \& C. L. Cartier (Eds.), The Chinese diaspora: Space, place, mobility, 
and identity (pp. 1-49). Lanham, MD: Rowman and Littlefield.

Soysal, Y. N. (2000). Citizenship and identity: Living in diasporas in postwar Europe? Ethnic and Racial Studies, 23(1), 1-15.

Stephenson, M. (2002). Travelling to the ancestral homelands: The aspirations and experiences of a UK Caribbean community. Current Issues in Tourism, 5(5), 378-425.

Suryadinata, L. (1987). Ethnic Chinese in Southeast Asia: Problems and prospects. Journal of International Affairs, 41(1), 135-135.

Tan, C. B. (2001). Chinese in Southeast Asia and identities in a changing global context. In M. J. Armstrong, R. W. Armstrong, \& K. Mulliner (Eds.), Chinese populations in contemporary southeast Asian societies: Identities, interdependence and international influence (pp. 210-236). Richmond: Curzon.

Tong, C., \& Chan, K. (2001). One face, many masks: The singularity and plurality of Chinese identity. Diaspora: A Journal of Transnational Studies, 10(3), 361-361.

Tu, W. (1991). Cultural China: The periphery as the centre. Daedalus, 120(2), 1-32.
Wang, G. (1991). China and the Chinese overseas. Singapore: Times Academic Press.

Wang, G. (1999). A single Chinese diaspora? some historical reflections. In G. Wang \& A. S. Wah (Eds.), Imagining the Chinese diaspora: Two Australian perspectives (pp. 29-31). Canberra: Centre for the Study of the Chinese Southern Diaspora.

Wang, L. L. (1994). Roots and the changing identity of the Chinese in the United States. In W. Tu (Ed.), The living tree: The changing meaning of being Chinese today (pp. 185-212). Stanford, CA: Stanford University Press.

Wickberg, E. (1994). The Chinese as overseas migrants. In J. M. Brown \& R. Foot (Eds.), Migration: The Asian experience (pp. 12-37). Basingstoke: Macmillan in association with St. Antony's College, Oxford.

Wu, D. (1994). The construction of Chinese and non-Chinese identities. In W. Tu (Ed.), The living tree: The changing meaning of being Chinese today (pp. 148-167). Stanford, CA: Stanford University Press.

Young, R. (1995). Colonial desire: Hybridity in theory, culture, and race. London: Routledge. 